\title{
The N-terminal fragment of the tomato torrado virus RNA1- encoded polyprotein induces a hypersensitive response (HR)-like reaction in Nicotiana benthamiana
}

\author{
Przemysław Wieczorek $^{1}$ - Aleksandra Obrępalska-Stęplowska ${ }^{1}$
}

Received: 19 November 2015/Accepted: 19 March 2016/Published online: 13 April 2016

(c) The Author(s) 2016. This article is published with open access at Springerlink.com

\begin{abstract}
The hypersensitive response (HR) is a defence reaction observed during incompatible plant-pathogen interactions in plants infected with a wide range of fungi, bacteria and viruses. Here, we show that an $\mathrm{N}$-terminal polyprotein fragment encoded by tomato torrado virus RNA1, located between the first ATG codon and the protease cofactor (ProCo) motif, induces an HR-like reaction in Nicotiana benthamiana. Agrobacterium tumefaciensmediated transient expression of the first 105 amino acids (the calculated molecular weight of the fragment was ca. $11.33 \mathrm{kDa}$, hereafter refered to as the $11 \mathrm{~K}$ domain) from ToTV RNA1 induced an HR-like phenotype in infiltrated leaves. To investigate whether the $11 \mathrm{~K}$ domain could influence the virulence and pathogenicity of a recombinant virus, we created a potato virus $\mathrm{X}(\mathrm{PVX})$ with the $11 \mathrm{~K}$ coding sequence inserted under a duplicated coat protein promoter. We found that $11 \mathrm{~K}$ substantially increased the virulence of the recombinant virus. Disease phenotype induced in $N$. benthamiana by PVX-11K was characterized by strong local and systemic necrosis. This was not observed when the $11 \mathrm{~K}$ domain was expressed from PVX in an antisense orientation. Further analyses revealed that the $11 \mathrm{~K}$ domain could not suppress posttranscriptional gene silencing (PTGS) of green fluorescent protein (GFP) in the $N$. benthamiana $16 \mathrm{c}$ line. In silico analysis of the predicted secondary structure of the $11 \mathrm{~K}$ domain indicated the presence of two putative helices that are highly
\end{abstract}

Aleksandra Obrępalska-Stęplowska

olaob@o2.pl

1 Interdepartmental Laboratory of Molecular Biology, Institute of Plant Protection-National Research Institute, 20 Władysława Węgorka St, 60-318 Poznan, Poland conserved in tomato-infecting representatives of the genus Torradovirus.

\section{Introduction}

Interactions between plants and pathogens represent an everlasting arms race between the invader and the host. These interactions also take place at the molecular level, involving nucleic acids and proteins of the pathogens (fungi, bacteria, viruses) as well as those of the plant. Viruses take advantage of the cellular machinery to replicate and spread within the host. This reprograms cell metabolism and leads to a sequence of events that negatively affect the development of the invaded plant.

Some viruses induce systemic necrosis in the plant upon infection [1]. In contrast to a hypersensitive reaction (HR), which limits the spread of the virus to a local focus of infection, systemic necrosis does not prevent the virus from further spreading within the infected host [2]. Importantly, systemic necrosis has been proposed to share some biochemical and physiological features with programmed cell death (PCD) [3].

Tomato torrado virus (ToTV), a member of the family Secoviridae, is an emerging pathogen of plants of the family Solanaceae, especially tomato (Solanum lycopersicum) $[4$, 5]. The virus is considered one of the most dangerous tomato pathogens because of its virulence, wide host range and increasing worldwide distribution [6]. In tomato, ToTV induces severe systemic necrosis, which further reduces plant growth. ToTV also infects Nicotiana benthamiana, inducing chlorosis and leaf malformation (Fig. 1A). ToTV has an RNA genome consisting of two single-stranded (+)RNAs. RNA1 (7829 nucleotides [nt]) encodes a long polyprotein (polyprotein 1) with putative motifs involved in 
A
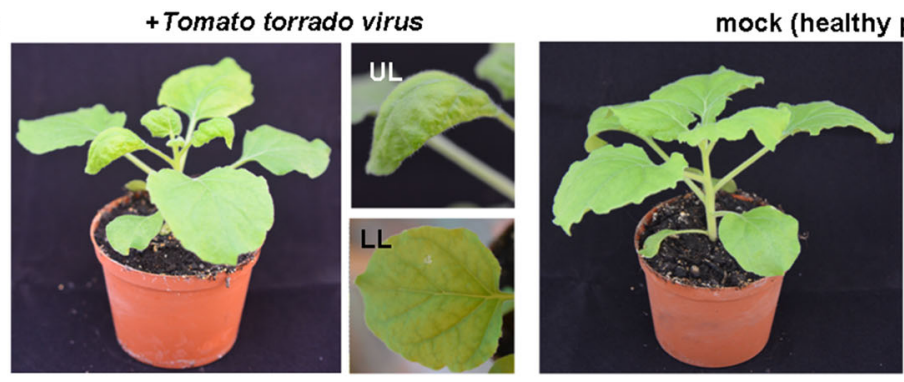

RNA1

.

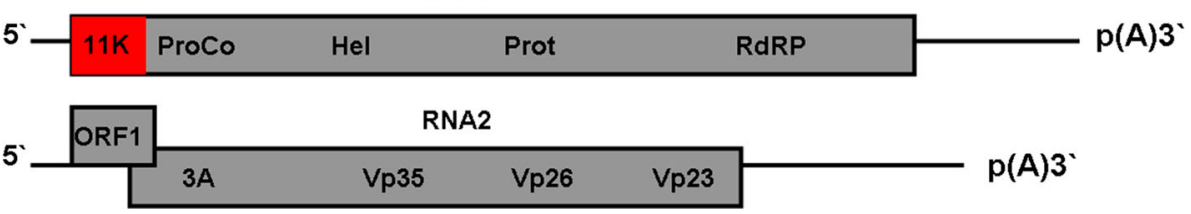

Fig. 1 A. Symptoms induced in Nicotiana benthamiana plants upon tomato torrado virus (ToTV) infection. Healthy (mock-inoculated) plants were included. UL and LL, magnification of upper and lower leaves, respectively. B. Schematic representation of the ToTV genome. The two RNA strands are shown. RNA1 encodes a polyprotein with protease cofactor (ProCo), helicase (Hel), protease (Prot) and RNA-dependent RNA polymerase (RdRP) domains. RNA2 contains an open reading frame of unknown function (ORF1), and ORF2, encoding a polyprotein with a movement protein domain (3A) and three coat protein subunits (Vp35, Vp26 and Vp23). Both RNA strands are polyadenylated (pA) and flanked by 5' and 3' untranslated regions. The red box highlights the position of the $11 \mathrm{~K}$ domain within the N-terminus of the RNA-encoded polyprotein (color figure online)

N-terminal part of ToTV polyprotein 1 . The putative short region, with a predicted molecular weight of $11.33 \mathrm{kDa}$ (thus refered to as the $11 \mathrm{~K}$ domain), induced an HR-like reaction when transiently expressed in $N$. benthamiana. Moreover, the $11 \mathrm{~K}$ domain substantially enhanced the severity of symptoms produced by infection with a chimeric potato virus $\mathrm{X}-11 \mathrm{~K}$ (PVX-11K). In many instances, the biological role of heterologously expressed viral proteins that induce necrosis in $N$. benthamiana has been correlated with their suppressive function during posttranscriptional gene silencing (PTGS) [10, 11]. However, our results did not confirm that the ToTV $11 \mathrm{~K}$ domain could suppress PTGS. Further sequence analysis of the $11 \mathrm{~K}$ indicated that the domain is likely to contain helical structures. The two predicted helices were found to be conserved in sequence among known tomato-infecting torradoviruses: tomato marchitez virus, tomato chocolate virus, tomato chocolate spot virus and tomato necrotic dwarf virus [12-15]. We discuss potential functions of the $11 \mathrm{~K}$ domain in the context of its conservation among members of the genus Torradovirus.

\section{Materials and methods}

\section{Plant material and virus source}

$N$. benthamiana plants (wild type and the 16c line, expressing the green fluorescent protein [GFP]) were grown under greenhouse conditions at $24-25{ }^{\circ} \mathrm{C}$. An 
infectious clone of the tomato torrado virus Kra isolate [16] was used as the virus source for plant inoculation.

\section{Cloning of the coding sequence of the putative $11 \mathrm{~K}$ domain}

All primers used in this study are listed in Table 1. Plants were inoculated with ToTV, and from those showing disease symptoms, total RNA was isolated using TRI Reagent (Life Technologies) as described previously [19]. Up to $2 \mu \mathrm{g}$ of the RNA was reverse transcribed using $100 \mathrm{ng}$ of random hexamers and $200 \mathrm{U}$ of RevertAid Reverse Transcriptase (Thermo Scientific). The cDNA was used for polymerase chain reaction (PCR) with primers flanking the sequence between the first ATG codon from ToTV RNA1 (the 5UTR/PrCo_F primer) and the first codon of the protease cofactor motif (the 5UTR/PrCo_R primer) within the same RNA1. After agarose gel electrophoresis (1\% agarose in TBE buffer), DNA fragments were extracted from the gel and cloned into two expression vectors: pBIN61 and pgR107 [20]. Briefly, the vectors were digested with SmaI and treated with alkaline phosphatase (Thermo Scientific). One hundred nanograms of the repurified SmaI-digested pBIN61 was used for recombination-based cloning with $300 \mathrm{ng}$ of PCR-amplified $11 \mathrm{~K}$ sequence using an In-Fusion cloning Kit (Clontech).

The SmaI-digested pgR107 vector was ligated to the PCR-amplified $11 \mathrm{~K}$ using T4 DNA ligase (Thermo Scientific). Both the recombination mixture and the ligation mixture were used to transform competent cells of $E$. coli strain TOP10 (Life Technologies). The recombined plasmid was extracted, its sequence was verified, and it was used for transformation of A. tumefaciens strains C58C1 (pBIN61-based constructs) or GV3101 (pgR107-based constructs).

\section{Local and systemic protein expression in $N$. benthamiana}

A suspension of $A$. tumefaciens carrying either the pBIN61- or pgR107-based expression vector were grown at $28^{\circ} \mathrm{C}$ for $24-48 \mathrm{~h}$ in $\mathrm{LB}$ medium with kanamycin and tetracycline. The bacteria were harvested and suspended in infiltration buffer (10 mM MES, $\mathrm{pH} 5.8,0.5 \mu \mathrm{M}$ acetosyringone, and $10 \mathrm{mM} \mathrm{MgCl}_{2}$ ) and kept at room temperature for at least $2 \mathrm{~h}$. The mixture was adjusted to an $\mathrm{OD}_{600}$ of 1.0 and used to infiltrate two leaves of 6-week-old $N$. benthamiana seedlings, which were subsequently maintained under greenhouse conditions at $24-25{ }^{\circ} \mathrm{C}$. Local protein expression was done using pBIN61-derived constructs, whereas both local and systemic expression of $11 \mathrm{~K}$ was carried out using pgR107-11K (the PVX-based expression vector). For each infiltration, at least five plants were used, and the entire experiment was performed three times.

\section{In-patch GFP silencing assay}

For the GFP-based silencing patch co-infiltration assay, the suspension of A. tumefaciens transformed with pBIN61GFP $\left(\mathrm{OD}_{600}\right.$ 0.1) was mixed with Agrobacterium $\left(\mathrm{OD}_{600}=1.0\right)$ transformed with either pBIN61-11K,

Table 1 Oligonucleotide primers used in this study

\begin{tabular}{|c|c|c|}
\hline Primer ID & Primer sequence $\left(5^{\prime} \rightarrow 3^{\prime}\right)$ & Primer application \\
\hline $\begin{array}{l}\text { 5UTR/ } \\
\text { PrCo_F }\end{array}$ & TCTAGAGGATCCCCCATGTCTTTTTCCAAGATGTTC & \multirow{2}{*}{$\begin{array}{l}\text { Cloning and expression of the ToTV } 11 \mathrm{~K} \text { coding sequence. } \\
\text { Start codon is in bold, stop codon is in italics. The } \\
\text { 15-nucleotide underlined sequence was used for } \\
\text { recombination-based cloning with pBIN61 }\end{array}$} \\
\hline $\begin{array}{l}\text { 5UTR/ } \\
\text { PrCo_R }\end{array}$ & GAATTCGAGCTCCССТCAATCACAAATTGATTTGTAC & \\
\hline qsGFP1 & CACATGAAGCAGCACGACTT & \multirow[t]{2}{*}{ Real-time RT-PCR, quantitation of GFP mRNA } \\
\hline qsGFP2 & TCCTTGAAGTCGATGCCCTT & \\
\hline PVX1 & GGATAGGAGTGGAACAATGA & \multirow{2}{*}{$\begin{array}{l}\text { Real-time RT-PCR, quantitation of PVX RNA-dependent RNA } \\
\text { polymerase gene }\end{array}$} \\
\hline PVX2 & САATTTCTCTCAATGCCTTC & \\
\hline pgR107_CPF & CGCAACTCCTGCCACAGCTTCA & \multirow[t]{2}{*}{ Real-time RT-PCR, quantitation of PVX coat protein gene } \\
\hline pgR107_CPR & GTCCCAAGCAGCCTGTGCCATA & \\
\hline pgr107_25KF & ACCGTGCATACACTCGGTGTCC & \multirow[t]{2}{*}{ Real-time RT-PCR, quantitation of PVX 25K gene } \\
\hline pgr107_25KR & CGAAATCGAAGCCACAGCCAGC & \\
\hline $\mathrm{NbActF}$ & GTGAAGGAGAAGTTGGCTTAC & \multirow{2}{*}{$\begin{array}{l}\text { Real-time RT-PCR raw data normalisation, quantitation of } N \text {. } \\
\text { benthamiana actin mRNA [17] }\end{array}$} \\
\hline NbAct2 & CTTCTGGGCAGCGGAATCTC & \\
\hline NbEF1aF & CACCATTGATATTGCCTTGTG & \multirow{2}{*}{$\begin{array}{l}\text { Real-time RT-PCR raw data normalisation, quantitation of } N \text {. } \\
\text { benthamiana EF1 } \alpha \text { mRNA [18] }\end{array}$} \\
\hline NbEF1aR & GTTCTTGATAAAGTCCCTGTG & \\
\hline
\end{tabular}


pBIN61-p19 or pBIN61 (empty vector) and co-infiltrated into leaves of $N$. benthamiana. Plants were maintained under greenhouse conditions at $24-25^{\circ} \mathrm{C}$. GFP fluorescence was excited using a hand-held UV lamp (UV Tech) and monitored $72 \mathrm{~h}$ after infiltration. Photographs were taken using a Nikon D5100 camera.

\section{RNA and protein analysis}

Total RNA was extracted as described previously [19]. For reverse transcription (RT) quantitative real-time PCR (RTqPCR), $1 \mu \mathrm{g}$ of total RNA was first treated with DNase (Thermo Scientific) and then subjected to cDNA synthesis. The resulting cDNA was used for RT-qPCR with the appropriate primers (Table 1) and $\mathrm{iTaq}^{\mathrm{TM}}$ universal SYBR ${ }^{\circledR}$ Green Supermix (Bio-Rad). The raw $\mathrm{Ct}$ data were normalised against actin or EF1 $\alpha$ mRNA.

Total soluble proteins were isolated from infiltrated leaf patches using extraction buffer (1 M Tris- $\mathrm{HCl}, \mathrm{pH}$ 7.5 , and $20 \%$ glycerol). The homogenate was centrifuged $\left(16,000 \times g, 30 \mathrm{~min}, 4^{\circ} \mathrm{C}\right)$ to remove cell debris, and the protein concentration was measured using a Bio-Rad Protein Assay (Bio-Rad). An equal amount $(50 \mu \mathrm{g})$ of the proteins was subjected to sodium dodecyl sulfate polyacrylamide gel electrophoresis (SDS-PAGE). After electrophoresis, proteins were electroblotted onto a PVDF filter (Roche), and GFP was probed using primary monoclonal antibody (anti-GFP monoclonal antibody, Thermo Scientific). The GFP protein was visualised using Western Blue $^{\circledR}$ Stabilized Substrate for Alkaline Phosphatase (Promega).

\section{Bioinformatic analysis}

Protein secondary structure was predicted using the GeneSilico Metaserver [21], and amino acid sequence alignments were done using ClustalW [22]. Sequence identities and similarities were calculated using BioEdit [23]. Protein sequence variability was assessed using the Protein Variability Server [24].

\section{Results}

\section{The ToTV 11K domain induces an HR-like phenotype in $N$. benthamiana}

To investigate the biological function of the $11 \mathrm{~K}$ domain, which is composed of 105 amino acid residues upstream of the protease cofactor (ProCo) motif encoded on ToTV RNA1 (Fig. 1B), the coding region between the 5'UTR and the ProCo motif was amplified by RT-PCR and was inserted into the pBIN61 vector. As shown in Fig. 2A,
A

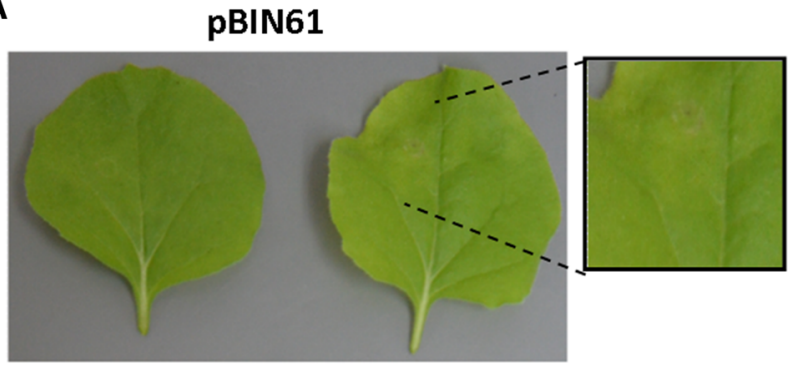

pBIN61-11K

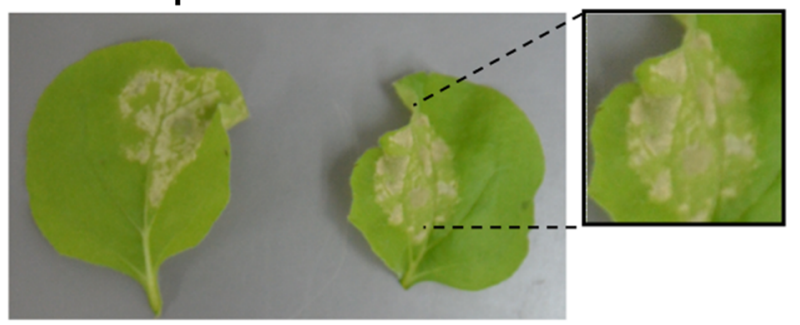

B

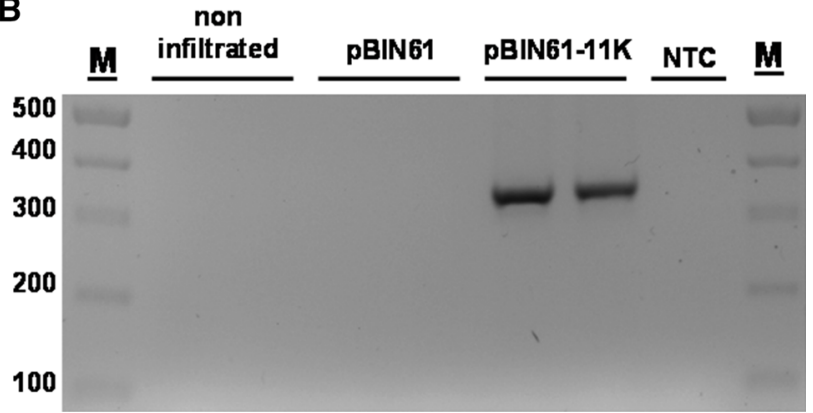

Fig. 2 The $11 \mathrm{~K}$ domain induces a hypersensitive response (HR)-like reaction in Nicotiana benthamiana. A. Leaves of $N$. benthamiana infiltrated with Agrobacterium tumefaciens carrying pBIN61 (upper panel) or pBIN61-11K vectors (lower panel). B. Detection of the $11 \mathrm{~K}$ coding sequence in $N$. benthamiana. RNA was isolated from infiltrated leaves and used for RT-PCR with $11 \mathrm{~K}$-specific primers. The amplicon of $c a .350 \mathrm{nt}$ was obtained only from plants infiltrated with pBIN61-11K. M, DNA mass ruler; NTC, no template control

when this construct was used to infiltrate $N$. benthamiana plants, an HR-like reaction was induced 72 hours post-infiltration (hpi) to produce pBIN61-11K. In comparison, patches infiltrated with the empty pBIN61 vector did not develop an HR-like phenotype. To determine whether the $11 \mathrm{~K}$ RNA was transcribed in leaf patches infiltrated with pBIN61-11K, total RNA was extracted from the infiltrated leaves, treated with DNase and used for RT-PCR. As expected, a $c a$. 350-nt 11K-specific amplicon was obtained only when RNA template extracted from HR expressing leaves was used. Neither the RNA isolated from non-infiltrated plants nor RNA extracted from patches infiltrated with pBIN61 gave the expected amplification product (Fig. 2B). This demonstrates that the $11 \mathrm{~K}$ domain ectopically expressed in $N$. benthamiana induces a cell-death-like reaction in the host. 


\section{The 11K peptide enhances the pathogenicity} of a chimeric PVX

Next, we investigated the effect of the ToTV $11 \mathrm{~K}$ domain on the pathogenicity of a mild virus. For this purpose, the $11 \mathrm{~K}$ domain was expressed in $N$. benthamiana using a PVX-based expression vector.

PVX expressed from the pgR107 plasmid induced mild disease symptoms in $N$. benthamiana, and in emerging leaves of the plants infected with pgR107, only a mild mosaic was observed (Fig. 3A). However, leaves infiltrated with $\mathrm{pgR} 107-11 \mathrm{~K}$ developed a cell-death phenotype that was already visible at 3 dpi. Symptoms were stronger than those displayed by plants expressing the $11 \mathrm{~K}$ domain from pBIN61-11K. Such a phenotype was not observed in leaves infiltrated with either pgR107 or pgR107-11Kas (Fig. 3A).

In the course of time, PVX infection expanded toward new leaves. PVX alone induced a mild disease phenotype in upper non-infiltrated leaves. Similar symptoms were observed in plants infected with PVX-11Kas. To assess whether the plants were actually infected with PVX or
PVX-11Kas, total RNA was extracted from upper non-infiltrated leaves and subjected to RT-PCR with $11 \mathrm{~K}$-specific primers. As expected, the ca. 350-nt amplicon was obtained from RNA isolated from PVX-11K- and PVX-11Kas-infected plants (Fig. 3B). However, only in plants infected with PVX-11K was strong systemic necrosis observed. Necrosis started to develop around the veins and proceeded to the entire leaf. The reaction was so strong that plants could not develop new apical leaves and thus remained stunted (Fig. 3A).

Next, we investigated whether the severe symptoms induced in PVX-11K-infected $N$. benthamiana were due to enhanced replication and therefore to an increase in accumulation of PVX-11K in infected tissues. For this purpose, total RNA was extracted from upper non-infiltrated leaves and used for RT-qPCR. The expression of three PVX genes (RdRP, 25K, and CP) was measured and normalized against the expression level of actin or $E F l \alpha$ genes. The results indicated that the levels of accumulated genomic (the RdRP gene) and subgenomic (25K and CP genes) PVX RNAs were comparable in plants infected with PVX,
Fig. 3 The $11 \mathrm{~K}$ domain enhances virulence of a chimeric potato virus $\mathrm{X}$ (PVX) in Nicotiana benthamiana. A. $N$. benthamiana plants infiltrated with Agrobacterium tumefaciens carrying an infectious clone of PVX or PVX-11K with the $11 \mathrm{~K}$ coding sequence in the sense or antisense orientation. B. RTPCR-based detection of $11 \mathrm{~K}$ transcripts in systemically infected leaves of $N$. benthamiana. The ca. 350-nt amplicon was obtained only from plants infected with PVX$11 \mathrm{~K}$. M, DNA mass ruler; NTC, no template control
A

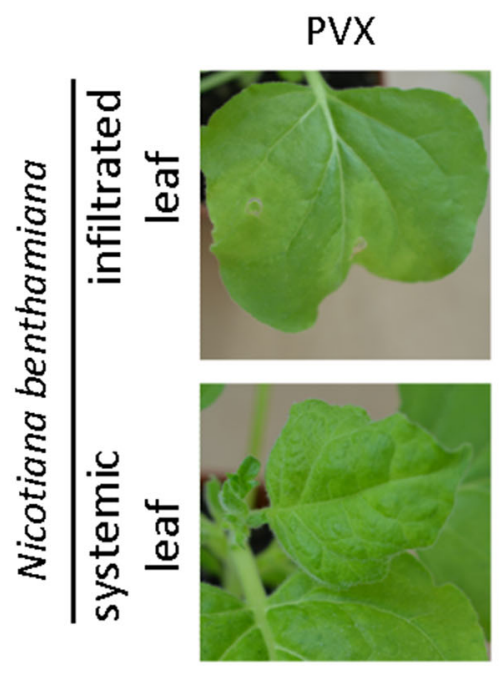

B

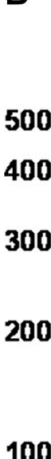

PVX-11K
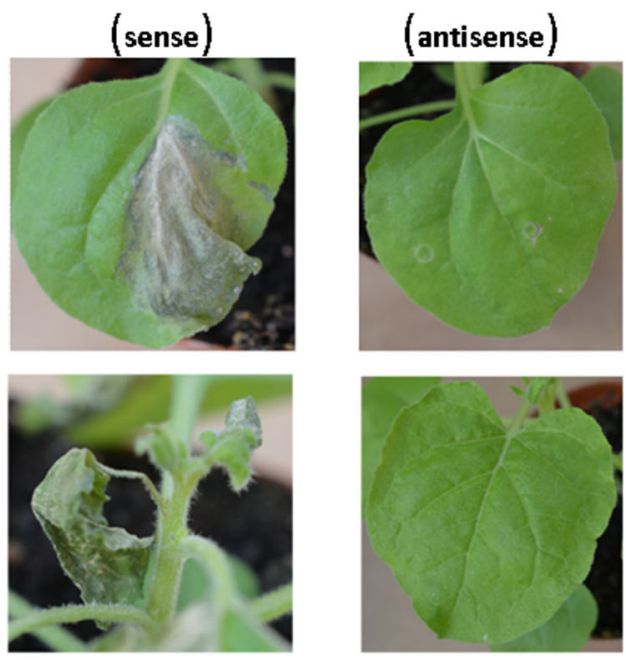

PVX-11K PVX-11K
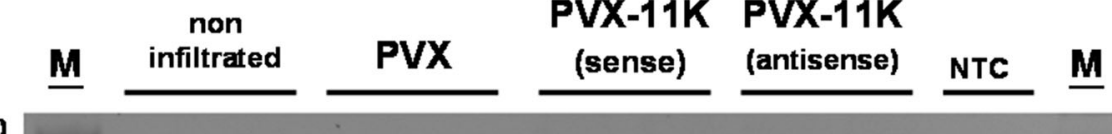

PVX-11K

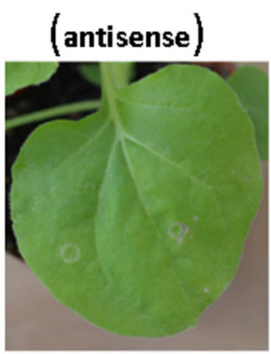

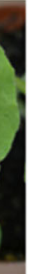

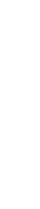

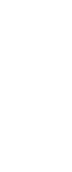




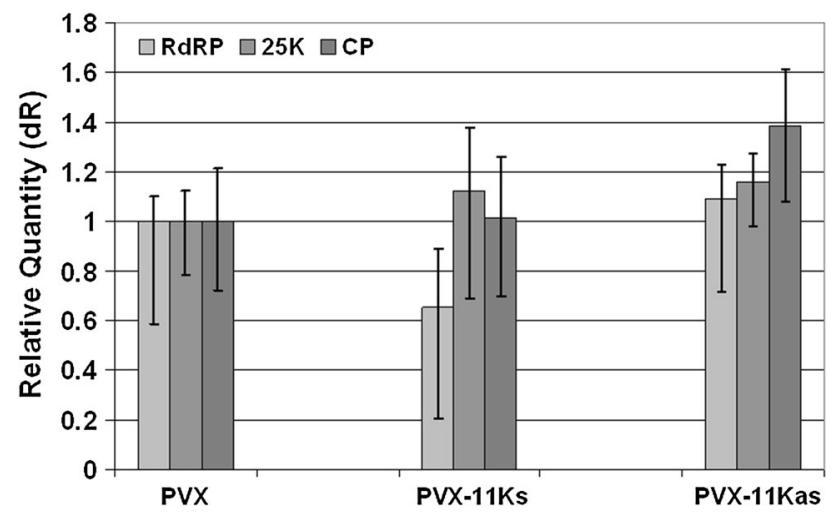

Fig. 4 Comparative analysis of potato virus X RNA accumulation in Nicotiana benthamiana plants infected with PVX, PVX-11K or PVX$11 \mathrm{Kas}$. The relative accumulation of three PVX open reading frames (RdRp, $25 \mathrm{~K}$ and $\mathrm{CP}$ ) was analysed by qRT-PCR

PVX-11K and PVX-11Kas (Fig. 4). In detail, the level of RdRP RNA decreased $c a$. 1.6-fold in plants infected with PVX-11K, whereas it increased slightly ( $c a .1 .2$-fold) in those infected with PVX-11Kas. The expression level of $25 \mathrm{~K}$ did not change considerably in PVX-11K-infected plants, but CP gene expression increased 1.4-fold in plants infected with PVX-11Kas, and it did not change in plants infected with PVX-11K (Fig. 4). This suggests that the severe disease symptoms observed in PVX-11K infection were not caused by a dramatic increase in PVX RNA expression but instead were induced by the biologically active $11 \mathrm{~K}$ domain.

\section{The 11K domain does not suppress PTGS in $N$. benthamiana}

Thomas et al. [25] reported previously that the P38 protein (coat protein) from turnip crinkle virus induces severe necrosis when ectopically expressed from a PVX vector. In the same study, the authors showed a possible role of P38 as a suppressor of RNA silencing. To verify the hypothesis that the disease symptoms induced in $N$. benthamiana upon $11 \mathrm{~K}$ expression were a consequence of suppression of PTGS pathways, a co-infiltration silencing assay was performed. Transient expression of GFP in $N$. benthamiana proceeded until 3 dpi and then decreased as a result of PTGS. However, in the presence of a PTGS suppressor, expression of the reporter gene was maintained at a high level. Indeed, at $3 \mathrm{dpi}$, strong GFP fluorescence was observed in leaf patches infiltrated with pBIN61-GFP together with pBIN61-p19 (a silencing suppressor protein of tomato bushy stunt virus [26]) (Fig. 5A). In comparison, GFP fluorescence was hardly observed in leaves infiltrated with pBIN61. Interestingly, in leaves co-expressing GFP and $11 \mathrm{~K}$, a brightening was observed (Fig. 5A). To determine whether the effect was caused by enhanced expression of GFP in infiltrated leaves, total soluble protein extracts were prepared from the GFP-expressing patches and were subjected to SDS-PAGE followed by western blot analysis with GFP-specific monoclonal antibodies. High GFP expression was confirmed in leaves co-infiltrated with pBIN61-GFP and pBIN61-p19 (Fig. 5B). However, in leaves expressing GFP together with pBIN61 or pBIN61$11 \mathrm{~K}$, the level of GFP was substantially lower. This suggests that the brightening in leaves infiltrated with pBIN61$11 \mathrm{~K}$ was not due to increased GFP expression. This was also confirmed by comparing GFP mRNA levels. Relative RT-qPCR analysis showed that GFP mRNA accumulated to the highest level only when co-expressed with the p19 silencing suppressor (Fig. 5C).

\section{The predicted secondary structure of the ToTV $11 \mathrm{~K}$ domain is conserved in the corresponding regions of tomato-infecting torradoviruses}

The consensus prediction of putative secondary structure motifs in the $11 \mathrm{~K}$ domain (based on eighteen predictors implemented in the GeneSilico Metaserver) indicated the potential to form two $\alpha$-helical motifs. Importantly, no $\beta$ sheets were predicted to be formed within the $11 \mathrm{~K}$ domain. Moreover, the predicted helical motifs consisted of two separate domains: helix 1 between amino acids 24 and 56, and helix 2 between amino acids 63 and 105 (Fig. 6A). The same analysis was performed for amino acid sequences of the corresponding regions of tomato marchitez virus, tomato necrotic dwarf virus, tomato chocolate virus and tomato chocolate spot virus. The two predicted helical motifs were found in all of the aforementioned viruses, at almost the same positions in their corresponding $11 \mathrm{~K}$ sequences (Fig. 6A). Interestingly, those two predicted helices were composed of amino acids with similar properties (Fig. 6B), and although the RNA sequence differs substantially between the analogous regions of other torradoviruses, the predicted secondary structures in their $11 \mathrm{~K}$ domains are highly conserved (Fig. 6B and C). Moreover, the proposed helix-building amino acids of the $11 \mathrm{~K}$ domain had the lowest variability score (Fig. 6D). This confirmed that although the two helices in the $11 \mathrm{~K}$ domain are sequence-defined, the domains have a conserved structure rather than a conserved sequence.

\section{Discussion}

Tomato torrado virus is an emerging pathogen of tomato, in which it induces severe systemic necrosis of leaves. Moreover, ToTV can infect $N$. benthamiana, inducing chlorosis and leaf malformations. Importantly, necrosis of locally or systemically infected leaves is not observed in 
Fig. 5 Analysis of posttranscriptional gene silencing (PTGS) suppressor activity of the ToTV $11 \mathrm{~K}$ domain. A. Leaves of Nicotiana benthamiana $16 \mathrm{c}$ infiltrated with mixtures of Agrobacterium tumefaciens cultures carrying GFP (pBIN61-GFP) and either an empty vector (pBIN61), the p19 PTGS suppressor from tomato bushy stunt virus (pBIN61-p19) or the ToTV $11 \mathrm{~K}$ domain (pBIN61-11K). B. Western blot analysis of GFP accumulation in infiltrated patches with p19 or $11 \mathrm{~K}$ expression. C. Accumulation of GFP mRNA expressed together with the tomato bushy stunt virus $\mathrm{p} 19$ or the ToTV $11 \mathrm{~K}$ domain
A
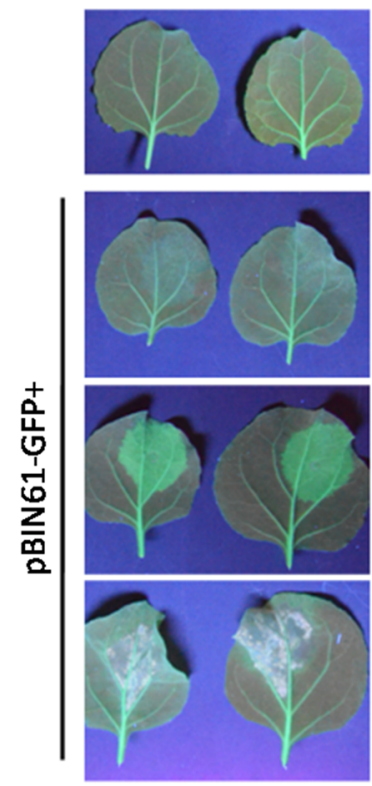

B

N. benthamiana $16 \mathrm{c}$

pBIN61

pBIN61-p19TБV

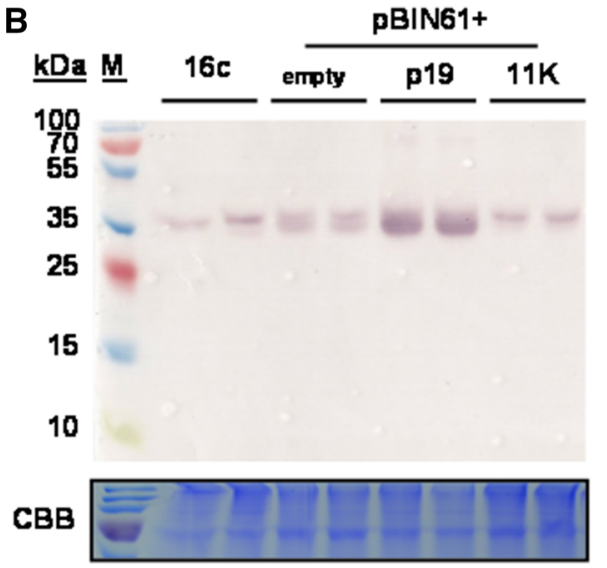

pBIN61-11KTaTY
ToTV-infected $N$. benthamiana. We previously showed that the host dependence of ToTV is determined at least in part by the ToTV movement protein (3A) [8]. In the present study, we show that a short domain of the ToTV RNA1 polyprotein, named the $11 \mathrm{~K}$ domain, can mediate an HR-like reaction in $N$. benthamiana.

Initially, we showed that the $11 \mathrm{~K}$ domain can trigger a local HR-like reaction when transiently expressed in $N$. benthamiana. Plants infected with PVX-11K developed severe systemic necrosis leading to death of plant shoots. However, this effect was not observed in tomato cv. Beta Lux (data not shown). A similar necrotic reaction on $N$. benthamiana was observed by Thomas et al. [25]. In their preliminary studies on the biological functions of the turnip crinkle virus (TCV) coat protein (P38), these authors showed that expression of $\mathrm{P} 38$ from a PVX vector led to induction of necrosis within the infiltrated leaves followed by plant shoot death. The same authors showed that the P38-trigerred necrosis was associated with increased accumulation of the PVX-P38 chimeric virus. Similarly, Aguilar et al. [27] described a local HR-like necrosis response induced upon expression of chimeric PVX in $N$. benthamiana. The authors used PVX with an inserted coding sequence of an RNA silencing suppressor: HCPro from plum pox virus or p19 from tomato bushy stunt virus. Expression of both proteins resulted, on one hand, in induction of an HR-like response in infiltrated leaves, and on the other hand, to increased accumulation of PVX subgenomic RNAs but not genomic RNA. These observations were characteristic for PVX expressing PTGS suppressors from other viruses. However, such an effect was not observed for the $11 \mathrm{~K}$ domain in our study. Accumulation of the necrosis-inducing PVX-11K in systemic leaves was comparable in symptomless PVX and PVX-11Kas.

Next, it was essential to determine whether the necrosisinducing $11 \mathrm{~K}$ was also able to suppress PTGS in transgenic $N$. benthamiana. Although some leaf brightening was observed in $N$. benthamiana leaves co-expressing GFP and the $11 \mathrm{~K}$ domain, we could not associate this effect with increased GFP accumulation. Western blot analysis and RT-qPCR confirmed the absence of PTGS suppressor activity of the $11 \mathrm{~K}$ domain.

The $11 \mathrm{~K}$ domain is comprised of 105 amino acid residues. In silico prediction indicated that at least $80 \%$ of the amino acid residues might be involved in forming the two long alpha helices. These two helices (helix 1 and helix2) are located at the same positions in the region corresponding to the $11 \mathrm{~K}$ domain of all tomato-infecting torradoviruses. This suggests that the conserved structure of the $11 \mathrm{~K}$ domain and the effect induced upon its expression in $N$. benthamiana (but not in tomato) might reflect the involvement of the $11 \mathrm{~K}$ domain in host-specific plant-virus interactions. We previously pointed out that the host 

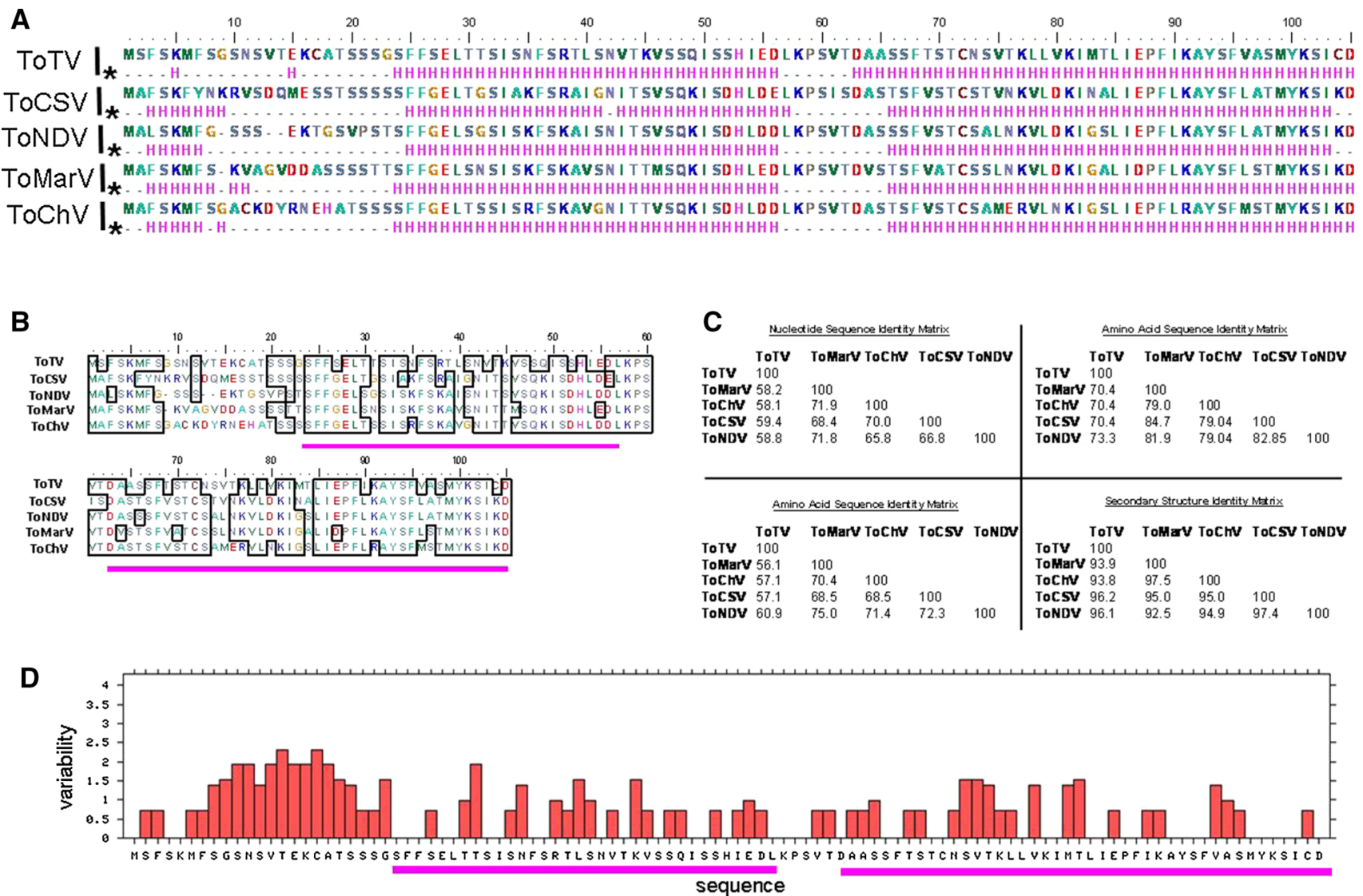

Fig. 6 Sequence comparison of the $11 \mathrm{~K}$ domains from tomatoinfecting torradoviruses. A. Amino acid sequence alignment of the $11 \mathrm{~K}$ domain. Primary structure and predicted helical domains (the rows marked with asterisks). $\mathrm{H}$, amino acids forming $\alpha$-helices. B. Sequence alignment of the corresponding $11 \mathrm{~K}$ domains of tomatoinfecting torradoviruses. Similar amino acids are outlined with black frames. Pink bars indicate predicted helices. C. Nucleotide, amino acid, and predicted helical domain similarity matrices of the $11 \mathrm{~K}$ domains of tomato-infecting torradoviruses. D. Sequence variability

specificity of ToTV might be mediated by its movement protein (3A) by showing that ToTV with an F210L mutation in the RNA2 polyprotein was not able to infect tomato cv. Beta Lux but remained infectious to $N$. benthamiana [8]. Moreover, single amino acid substitutions in Vp26 (one of the three ToTV coat protein subunits) diminished the ability of ToTV to infect tomato [Wieczorek et al. submitted]. The same substitutions had no effect on ToTV infectivity in $N$. benthamiana. Therefore, it cannot be ruled out that the biological activity of the ToTV $11 \mathrm{~K}$ domain acts in a host-specific manner.

It was previously shown that helical motifs in different viral proteins might be involved in induction of diseaselike symptoms in $N$. benthamiana. Mochizuki et al. [28] showed that necrotic spots appeared on $N$. benthamiana upon expression of the replication protein p29 of melon necrotic spot virus. By creating several deletion variants of plot of the $11 \mathrm{~K}$ domain of tomato-infecting torradoviruses. The calculation was made according to Shannon's method [24]. A score ( $y$-axis) of 0 indicates conserved amino acids. A score higher than 0 indicate variable amino acid positions. The pink bars indicate the locations of the two predicted helical motifs. ToTV, tomato torrado virus; ToMarV, tomato marchitez virus; ToCSV, tomato chocolate spot virus; ToChV, tomato chocolate virus; ToNDV, tomato necrotic dwarft virus (color figure online)

p29, the authors pointed out a potential hydrophobic $\alpha$ helix in transmembrane domain 2 (TMD2) as essential for inducing necrotic spots in $N$. benthamiana. Hashimoto et al. [29] showed that a putative amphipathic helix in the helicase protein $(\mathrm{Hel})$ of radish mosaic virus is responsible for membrane modification leading to cell death and necrotic symptoms in $N$. benthamiana.

Little is known about ToTV replication, and likewise, there are no data describing whether ToTV replication complexes form in association with cell membranes. Membrane-associated viral proteins might contain transmembrane motifs or amphipathic helices that are likely to modify host membranes. Hashimoto et al. [29] tested whether other amphipathic helix-containing viral proteins of two other members of the family Secoviridae would induce a cell death phenotype in $N$. benthamiana. Indeed, amphipathic helix-containing Hel proteins of cowpea 
mosaic virus and tobacco ringspot virus induced cell death when expressed in $N$. benthamiana, although the viruses do not induce systemic necrosis in the host. Consistent with this, it should be kept in mind that naturally infecting ToTV does not induce systemic necrosis in $N$. benthamiana. Komatsu et al. [30] showed that the necrosis-inducing activity of Plantago asiatica mosaic virus RNA-dependent RNA polymerase triggered systemic necrosis in $N$. benthamiana in a dose-dependent manner and was modulated by its helicase domain. In this light, the molecular mode of action of the necrosis-inducing ToTV $11 \mathrm{~K}$ domain might be more complex. Importantly, it should be taken into account that not all amphipathic helices are directly responsible for induction of a cell death phenotype [31]. Therefore, in the case of the ToTV $11 \mathrm{~K}$ domain, its putative amphipathic helix and other potential necrosis-modulating factors have to be more precisely analysed in the context of ToTV infectivity in $N$. benthamiana.

Acknowledgments We would like to thank D. Baulcombe (University of Cambridge, UK) for providing the pgR107, pBIN61 and pBIN61-p19 plasmids and GFP-transgenic $N$. benthamiana $16 \mathrm{c}$. This work was funded by grant no 2011/NZ9/07131 from the Polish National Centre of Science.

\section{Compliance with ethical standards}

The authors declare no conflicts of interest. This article does not contain any studies with human participants or animals performed by any of the authors.

Open Access This article is distributed under the terms of the Creative Commons Attribution 4.0 International License (http://crea tivecommons.org/licenses/by/4.0/), which permits unrestricted use, distribution, and reproduction in any medium, provided you give appropriate credit to the original author(s) and the source, provide a link to the Creative Commons license, and indicate if changes were made.

\section{References}

1. Ozeki J, Takahashi S, Komatsu K, Kagiwada S, Yamashita K, Mori T, Hirata H, Yamaji Y, Ugaki M, Namba S (2006) A single amino acid in the RNA-dependent RNA polymerase of Plantago asiatica mosaic virus contributes to systemic necrosis. Arch Virol 151:2067-2075

2. Mandadi KK, Scholthof KB (2013) Plant immune responses against viruses: how does a virus cause disease ? Plant Cell 25:1489-1505

3. Komatsu K, Hashimoto M, Ozeki J, Yamaji Y, Maejima K, Senshu H, Himeno M, Okano Y, Kagiwada S, Namba S (2010) Viral-induced systemic necrosis in plants involves both programmed cell death and the inhibition of viral multiplication, which are regulated by independent pathways. Mol Plant Microbe Interact 23:283-293

4. Verbeek M, Dullemans AM, van den Heuvel JF, Maris PC, van der Vlugt RA (2007) Identification and characterisation of tomato torrado virus, a new plant picorna-like virus from tomato. Arch Virol 152:881-890
5. Budziszewska M, Obrepalska-Steplowska A, Wieczorek P, Pospieszny $\mathrm{H}$ (2008) The nucleotide sequence of a Polish isolate of Tomato torrado virus. Virus Genes 37:400-406

6. Moodley V, Gubba A, Mafongoya PL (2015) First report of Tomato torrado virus on tomato (Solanum lycopersicum) in South Africa. Plant Dis. doi:10.1094/PDIS-06-15-0683-PDN

7. Budziszewska M, Wieczorek $\mathrm{P}$, Zhang $\mathrm{Y}$, Frishman $\mathrm{D}$, Obrępalska-Stęplowska A (2015) Genetic variability within the Polish tomato torrado virus Kra isolate caused by deletions in the 3'-untranslated region of genomic RNA1. Virus Res 185:47-52

8. Wieczorek P, Obrępalska-Stęplowska A (2015) A single amino acid substitution in movement protein of tomato torrado virus influences ToTV infectivity in Solanum lycopersicum. Virus Res. doi:10.1016/j.virusres.2015.11.008

9. Wang KD, Empleo R, Nguyen TT, Moffett P, Sacco MA (2015) Elicitation of hypersensitive responses in Nicotiana glutinosa by the suppressor of RNA silencing protein $\mathrm{P} 0$ from poleroviruses. Mol Plant Pathol 16:435-548

10. van WR, Dong X, Liu H, Tien P, Stanley J, Hong Y (2002) Mutation of three cysteine residues in Tomato yellow leaf curl virus-China C2 protein causes dysfunction in pathogenesis and posttranscriptional gene-silencing suppression. Mol Plant Microbe Interact 15:203-208

11. Wieczorek P, Obrępalska-Stęplowska A (2015) Suppress to survive-implication of plant viruses in PTGS. Plant MolBiol Rep 33:335-346

12. Verbeek M, Dullemans AM, van den Heuvel JF, Maris PC, van der Vlugt RA (2008) Tomato marchitez virus, a new plant picorna-like virus from tomato related to tomato torrado virus. Arch Virol 153:127-134

13. Verbeek M, Dullemans A, van den Heuvel H, Maris P, van der Vlugt R (2010) Tomato chocolate virus: a new plant virus infecting tomato and a proposed member of the genus Torradovirus. Arch Virol 155:751-755

14. Batuman O, Kuo YW, Palmieri M, Rojas MR, Gilbertson RL (2010) Tomato chocolate spot virus, a member of a new torradovirus species that causes a necrosis-associated disease of tomato in Guatemala. Arch Virol 155:857-869

15. Wintermantel WM, Hladky IL (2013) Genome characterization of Tomato necrotic dwarf virus, a torradovirus from southern California. Phytopathology 103:S160

16. Wieczorek P, Budziszewska M, Obrępalska-Stęplowska A (2015) Construction of infectious clones of tomato torrado virus and their delivery by agroinfiltration. Arch Virol 160:517-521

17. Obrępalska-Stęplowska A, Wieczorek P, Budziszewska M, Jeszke A, Renaut J (2013) How can plant virus satellite RNAs alter the effects of plant virus infection ? A study of the changes in the Nicotiana benthamiana proteome after infection by peanut stunt virus in the presence or absence of its satellite RNA. Proteomics 13:2162-2175

18. Obrępalska-Stęplowska A, Budziszewska M, Wieczorek P, Czerwoniec A (2012) Analysis of two strains of Peanut stunt virus: satRNA-associated and satRNA free. Virus Genes 44:513-521

19. Wieczorek P, Wrzesińska B, Obrępalska-Stęplowska A (2013) Assessment of reference gene stability influenced by extremely divergent disease symptoms in Solanum lycopersicum L. J Virol Methods 194:161-168

20. Jones L, Hamilton AJ, Voinnet O, Thomas CL, Maule AJ, Baulcombe DC (1999) RNA-DNA interactions and DNA methylation in post-transcriptional gene silencing. Plant Cell 11:2291-2301

21. Kurowski MA, Bujnicki JM (2003) GeneSilico protein structure prediction meta-server. Nucleic Acids Res 31:3305-3307

22. Larkin MA, Blackshields G, Brown NP, Chenna R, McGettigan PA, McWilliam H, Valentin F, Wallace IM, Wilm A, Lopez R, 
Thompson JD, Gibson TJ, Higgins DG (2007) Clustal W and Clustal X version 2.0. Bioinformatics 23:2947-2948

23. Hall TA (1999) BioEdit: a user-friendly biological sequence alignment editor and analysis program for Windows 95/98/NT. Nucleic Acids Sym Ser (Oxf) 41:95-98

24. Garcia-Boronat M, Diez-Rivero CM, Reinherz EL, Reche PA (2008) PVS: a web server for protein sequence variability analysis tuned to facilitate conserved epitope discovery. Nucleic Acids Res 36:W35-W41

25. Thomas CL, Leh V, Lederer C, Maule AJ (2003) Turnip crinkle virus coat protein mediates suppression of RNA silencing in Nicotiana benthamiana. Virology 306:33-41

26. Voinnet O, Rivas S, Mestre P, Baulcombe D (2003) An enhanced transient expression system in plants based on suppression of gene silencing by the p19 protein of tomato bushy stunt virus. Plant J 33:949-956

27. Aguilar E, Almendral D, Allende L, Pacheco R, Chung BN, Canto T, Tenllado F (2015) The P25 protein of potato virus $\mathrm{X}$ (PVX) is the main pathogenicity determinant responsible for systemic necrosis in PVX-associated synergisms. J Virol 89:2090-2103
28. Mochizuki T, Hirai K, Kanda A, Ohnishi J, Ohki T, Tsuda S (2009) Induction of necrosis via mitochondrial targeting of Melon necrotic spot virus replication protein p29 by its second transmembrane domain. Virology 390:239-249

29. Hashimoto M, Komatsu K, Iwai R, Keima T, Maejima K, Shiraishi T, Ishikawa K, Yoshida T, Kitazawa Y, Okano Y, Yamaji Y, Namba S (2015) Cell death triggered by a putative amphipathic helix of radish mosaic virus helicase protein is tightly correlated with host membrane modification. Mol Plant Microbe Interact 28:675-688

30. Komatsu K, Hashimoto M, Maejima K, Shiraishi T, Neriya Y, Miura C, Minato N, Okano Y, Sugawara K, Yamaji Y, Namba S (2011) A necrosis-inducing elicitor domain encoded by both symptomatic and asymptomatic Plantago asiatica mosaic virus isolates, whose expression is modulated by virus replication. Mol Plant Microbe Interact 24:408-420

31. Liu L, Westler WM, den Boon JA, Wang X, Diaz A, Steinberg HA, Ahlquist P (2009) An amphipathic alpha-helix controls multiple roles of brome mosaic virus protein 1a in RNA replication complex assembly and function. PLoS Pathog 5:e1000351 